\title{
Do States Free Ride in Antitrust Enforcement?
}

\author{
Robert M. Feinberg and Thomas A. Husted \\ American University
}

October 2011

\begin{abstract}
Recent research has documented a substantial role in antitrust enforcement by U.S. states. While many of the cases litigated involve small local firms, a non-trivial portion encompass multiplestate issues. Some previous literature has investigated whether states engage in free-riding behavior in environmental regulation, and whether governments free ride on private decisions in provision of public goods. In this paper, we analyze a sample of antitrust cases involving crossstate impacts (from the Multi-State Antitrust Database, provided by the National Association of Attorneys General) and explain the determinants of free-riding (which we define as participating in a case, but not as a lead plaintiff).
\end{abstract}




\section{Introduction}

Recent research has examined the role of state governments in the U.S. in antitrust enforcement over the past 20 years. What has not been explored is the extent to which states make strategic decisions on their involvement in antitrust litigation. In particular, while most state antitrust cases involve purely local matters, a significant number of these concern more than one state; states then need to decide whether to invest in leading an investigation, or letting other states take the lead and participating in some lesser role, which includes simply signing on to a settlement. We view the decision by a state to delay entry into antitrust litigation to be a type of "free riding" behavior. In this paper we analyze this issue of "free-riding" by states in antitrust activity.

\section{Previous literature}

One of the defining characteristics of a pure public good is the nonexcludability of the benefits from its consumption. Since benefits can be received by individuals without having to pay for the goods, this nonexcludability creates the possibility for a "free rider problem." As a consequence of this free riding behavior, the private market cannot exact a price for this good and this may mean the private market will provide a suboptimal amount of the good. Free riders are usually used as justification for government intervention into the private market to allocate these so called public goods in order to correct the market failure. While this behavior would seem rational, it is not easily observed so the extent of free riding is not generally known. Researchers have employed experimental game evidence to measure the extent of free riding, with results ranging from none to an extreme amount. Factors found in this literature that appear to decrease the degree of free riding behavior under certain conditions include smaller group size 
[Isaac, Walker and Thomas (1984)], experience through repeated game play [Fischbacher and Gachter (2010)], pre-game communication among participants, and an ability to exclude players from the group or other sanctions [Delmas and Keller (2005)]

While the free rider problem and the experimental evidence have focused on private market decision makers, it is straightforward to extend these behaviors to self-interested governments. One possibility is that governments reduce the amount of certain appropriations as a result of private contributions. Becker and Linsday (1994) find a considerable degree of government free riding behavior in the context of appropriations to public higher education institutions. An alternative source of free riding does not involve the private sector, but is between government activities, particularly those with significant spillover effects. Lee (1988) considers the issue of free-riding among countries in their efforts devoted to fighting terrorism. More recently, Sav (2010) finds a similar impact. Chari and Kehoe (2007) provide a theoretical discussion of what they call a free-rider problem among members of a monetary union in their fiscal and regulatory policies, caused by an inability of the monetary authority to commit to their policies.

Sigman (2002) finds that water pollution control is affected by the degree of spillovers crossing international borders. Somewhat closer to the focus of this paper, Konisky and Woods (2010) investigate whether U.S. states free ride in environmental regulatory actions. Their results are somewhat mixed; while they report some impact in reducing state enforcement of the Clean Air Act in their counties adjacent to international borders, they do not find this pattern in counties bordering other U.S. states.

A recent theoretical paper by Choi and Gerlach (2009) raises the concern that national antitrust enforcement in a global economy (with multi-market contact among exporters) may be 
sub-optimal due to free-riding on the antitrust activity of other countries. However, no empirical evidence is provided. No previous work has examined whether state antitrust enforcement can be viewed in terms of free-riding. Recent work [Feinberg and Reynolds (2010)] has documented the significant amount of state antitrust activity ongoing and explained this activity in terms of economic and political factors, as well as noting its impact on business entry and relocation decisions at the state level [Feinberg and Husted (2011)].

A significant number of antitrust cases concern more than one state and, as a result, the outcome of these cases could potentially benefit several states. Free-riding by states in the decision to participate in multistate antitrust litigation is similar to the situations described above. States have the option of joining the litigation at any stage of the process, ranging from initiating the litigation to joining the litigation at settlement. Each state's attorney general has the authority to make the decision to enter into these multistate antitrust lawsuits. Provost (2010) argues the state attorney general's decision will depend on policy motivations, related to the interests of the state population, and political considerations, related to the attorney general's political party or electoral ambitions. The importance and intensity of these motivations and political circumstances will vary considerably across the states, so it is highly likely that each state will behave differently in the timing of its entry into the litigation process. A key aspect is that states can benefit from such an outcome even if they do not lead the antitrust investigation or even if they take an active role from the beginning. As a result, on the assumption that other states will bear the greater cost of initiating the case, there is considerable incentive for state governments to act "selfishly" and reduce costs by deferring and joining any antitrust suit later in the investigation. In what follows we explore the role of free-riding by states in this area. 


\section{Data and Methodology}

Based on the Antitrust Multistate Litigation Database (for the years 1990-2006) put together by the National Association of Attorneys General, we analyze all state-by-case observations where more than one state was involved at any stage of the case (as either "lead plaintiff", "participating state", or "settling state") ; we interpret this as the set of cases in which there were expected to be benefits beyond a single state - so the possibility of free-riding would exist. There are a total of 1181 observations, involving 47 distinct cases and all 50 states.

We define two alternative "free-riding" dependent variables, participation as other than the lead plaintiff (NotLead), which might be thought of as "weak" free-riding, and participation only at the settlement stage of the case (Settlement), which could be viewed as "strong" free-riding. As these dependent variables are binary, we estimate this model using a probit analysis.

The included explanatory variables define the underlying legal, economic, and political circumstances of these cases. The type of case may be an important indicator both of the complexity - hence cost - and likely benefits of involvement in the litigation. Horizontal conspiracy (Horizontal Case) and merger cases (Merger Case) raise relatively straightforward economic and legal issues and have potential benefits to the plaintiff which are likely to be reasonably well predicted ex ante. Other cases, which may seem more costly and with more uncertain benefits e.g., vertical issues, monopolization, restrictive contracts, etc) might be expected to lead to greater free-riding behavior.

As described above, states can enter into antitrust cases later and still enjoy the benefits from any settlement. It is expected, then, that states with more resources are less likely to free ride. We measure these resources along several dimensions: the size of the state economy 
(GSP), the relative importance of government expenditures in the state (Gov't Share of GSP), and per capita income (Income). We expect to observe that larger, more affluent, states, with relatively larger government sectors (and hence greater resources available) are more likely to take the lead on antitrust enforcement -and hence less likely to free-ride on other states' activity. The existence of federal resources as a result of its involvement in these cases (Federal Involvement) should reduce the need for immediate state involvement and, therefore, increase the amount of state free riding.

As described earlier, one of the key determinants of free riding is the number of individual parties involved in the transaction. We include a measure of the number of states included in any stage of the multistate litigation (Number of States) to capture this effect. Two variables are included to describe the political circumstances involving the state attorney general - whether the AG is from the Republican party (GOP AG) and whether the AG is appointed (Appointed AG). Feinberg and Reynolds (2010) found that Republican AGs and appointed AGs were less likely to participate in antitrust cases; we examine whether this reluctance extends to a more limited role (more free-riding) where they do participate. Summary statistics for the dependent and independent variables are presented in Table 1.

\section{Results}

Marginal estimates, evaluated at the mean values of the independent variables, from a probit estimation of the probability of participating in a case as other than the lead plaintiff are presented in Tables 2 and 3. Results from the "weak" form of free riding, where the state is participating in a nonlead role, are presented in Table 2. The results from the "strong" form of free riding, where the state enters only at the settlement stage, are presented in Table 3 . While 
there are differences in the marginal effects between the two models, there are some consistent findings. In both models, the number of states participating in the litigation increases the free riding behavior and the resources available to the state government, measured by both the state GSP and the relative size of the government sector, decreases both weak and strong free riding behavior, as expected. In addition, political effects do not seem to motivate either the weak or strong forms of free riding behavior.

We do find some interesting differences in coefficient estimates between the weak and strong free riding models. States are less likely to free-ride in a strong way (i.e., only participating at the settlement stage) on horizontal and merger cases; the implication then is that there is more likely to be strong free-riding on more complicated/controversial cases where benefits (and perhaps costs) are more difficult to determine (and more uncertain) ex ante; for these, as the case proceeds, better information may emerge and states may join in. We also find that the presence of federal involvement in a case has a sizeable positive effect on strong (but not weak) free-riding; states seem assured that sufficient resources will be available to pursue a case and they can then join in at the end.

\section{Conclusion}

Free-riding by government entities has been little-studied. No previous empirical research has examined whether state governments engage in free-riding in their enforcement of state and federal antitrust statutes. In this paper, we provide evidence that availability of governmental resources, potential number of states involved, the type of antitrust case, and the help of the federal government all play their expected roles in determining this type of freeriding. 
The social welfare implications of this free-riding behavior are unclear. Traditional analyses of free-riding view it as leading to suboptimal provision of some activity by individuals - leading to the role of government to step in and resolve this market failure. Does free-riding by states imply suboptimal antitrust case-filing activity? One might view the ability of the federal government to step in and file cases as a mechanism which deals with any such suboptimal state enforcement. However, analysis of this issue is beyond the scope of this paper. 


\section{REFERENCES}

Becker, Elizabeth and Cotton M. Lindsay, "Does the Government Free Ride?" Journal of Law and Economics, Vol. 37, No. 1 (April 1994), pp. 277-296.

Chari, V.V. and Patrick J. Kehoe, "On the need for fiscal constraints in a monetary union," Journal of Monetary Economics, Vol. 54, No. 8 (November 2007), pp. 2399-2408.

Choi, Jay Pil and Heiko Gerlach, "International Antitrust Enforcement and Multi-Market Contact," CESifo Working Paper No. 2599, March 2009

Delmas, Magali and Arturo Keller, "Free Riding in Voluntary Environmental Programs: The Case of the U.S. EPA WasteWater Program,” Policy Sciences, Vol. 38 (2005): 91-106.

Feinberg, Robert M. and Kara M. Reynolds, "The Determinants of State-Level Antitrust Activity," Review of Industrial Organization, Vol. 37, No. 3 (November 2010), pp. 179-196.

Feinberg, Robert M. and Thomas A. Husted, "Patterns of Establishment Entry and State-Level Antitrust Activity," Journal of Competition Law and Economics, 2011; doi:

10.1093/joclec/nhr013.

Isaac, R. Mark, James M. Walker and Susan H. Thomas, "Divergent Evidence on Free Riding: An Experimental Examination of Possible Explanations," Public Choice, Vol. 43, No. 2 (1984), pp. 113-149

Fischbacher, Urs and Simon Gachter, "Social Preferences, Beliefs, and the Dynamics of Free Riding in Public Goods Experiments," American Economic Review, Vol. 100, No. 1 (March 2010), pp. 541-556.

Konisky, David M. and Neal D. Woods, "Exporting Air Pollution? Regulatory Enforcement and Environmental Free Riding in the United States," Political Research Quarterly, Published online before print April 10, 2009, doi: 10.1177/1065912909334429 .

Lee, Dwight R., "Free Riding and Paid Riding in the Fight Against Terrorism," American Economic Review Papers and Proceedings, Vol. 78, No. 2 (May 1988), pp. 22-26.

Provost, Colin, “An Integrated Model of U.S. State Attorney General Behavior in Mult-State Litigation," State Politics and Policy Quarterly, Vol. 10, No. 1 (Spring 2010): 1-24.

Sav, G. Thomas, "Private Giving Crowding Government Funding in Public Higher Education," American Journal of Economics and Business Administration, Vol. 2, No. 3 (2010), pp. 293-299. 
Table 1. Descriptive Statistics, $N=1181$

\begin{tabular}{lllll} 
Variable & Mean & \multicolumn{1}{c}{ Std Dev } & Min & Max \\
\hline \multicolumn{1}{c}{ Dep Vars } & & & 0 & 1 \\
NotLead & 0.909 & 0.287 & 0 & 1 \\
Settlement & 0.189 & 0.392 & & \\
$\quad$ Indep Vars & & & 0 & 1 \\
Federal & 0.667 & 0.471 & 0 & 1 \\
Involvement & & & 0 & 1 \\
Horizontal Case & 0.256 & 0.436 & 0.312 & 51 \\
Merger Case & 0.109 & 14.71 & 3 & 0.281 \\
Number of States & 41.41 & 0.035 & 0.069 & 1512852 \\
$\begin{array}{l}\text { Gov't Share of } \\
\text { GSP }\end{array}$ & 0.128 & & 14010 & 72679 \\
GSP & 208315.2 & 243206.1 & 30478.8 & 1 \\
Income & 50529.4 & 7836.05 & 0 & 1 \\
GOP AG & 0.332 & 0.471 & 0 & \\
Appointed AG & 0.087 & 0.282 & & \\
\hline
\end{tabular}


Table 2. Probit Results: Dependent Variable="Weak" Free Riding (NotLead=Participation in a case other than as the lead plaintiff)

Independent Variable Marginal Effects

Federal Involvement $\quad-0.002(0.14)$

Horizontal Case $\quad 0.002(0.12)$

Merger Case $\quad-0.013(0.55)$

Number of States $\quad 0.0019(4.28)^{* * *}$

$\begin{array}{ll}\text { Gov't Share of GSP } & -0.437(2.12)^{* *} \\ \text { Ln(GSP) } & -0.057(8.70)^{* * *} \\ \text { Ln(Income) } & -0.006(0.15) \\ \text { GOP AG } & 0.0093(0.81)\end{array}$

Appointed AG $\quad 0.012(0.46)$

$\begin{array}{ll}\text { Pseudo } \mathbf{R}^{2} & 0.259\end{array}$

$\mathrm{N}=1181$

Z-statistics in parentheses next to estimated coefficients.

$*, * *, * * *$ denote statistical significance at $10 \%, 5 \%, 1 \%$, respectively. 
Table 3. Probit Results: Dependent Variable="Strong" Free Riding (Settlement=Participation in a case only at settlement)

Independent Variable Marginal Effects

$\begin{array}{lcc}\text { Federal Involvement } & 0.174 & (8.51)^{* * *} \\ \text { Horizontal Case } & -0.177 & (7.91)^{* *} \\ \text { Merger Case } & -0.151 & (3.14)^{* * *}\end{array}$

Number of States $\quad 0.0039(2.79)^{* * *}$

\begin{tabular}{lll} 
Gov't Share of GSP & -0.659 & $(2.72)^{* * *}$ \\
\hline Ln(GSP) & -0.061 & $(9.18)^{* * *}$ \\
\hline Ln(Income) & -0.037 & $(0.83)$ \\
\hline GOP AG & 0.0064 & $(0.56)$
\end{tabular}

Appointed AG $\quad 0.020 \quad(0.81)$

\begin{tabular}{ll} 
Pseudo R & $\mathbf{R}^{2}$ \\
\hline $\mathrm{N}=1181$ & 0.254
\end{tabular}

$\mathrm{Z}$-statistics in parentheses next to estimated coefficients.

$*, * *, * * *$ denote statistical significance at $10 \%, 5 \%, 1 \%$, respectively. 